\title{
ВОПРОСЫ АННЕНКОВЕДЕНИЯ
}

\author{
№ 92 май 2014
}

Анненковеды всех стран, соединяйтесь!

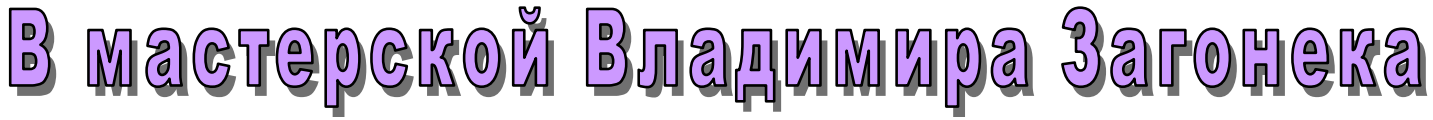

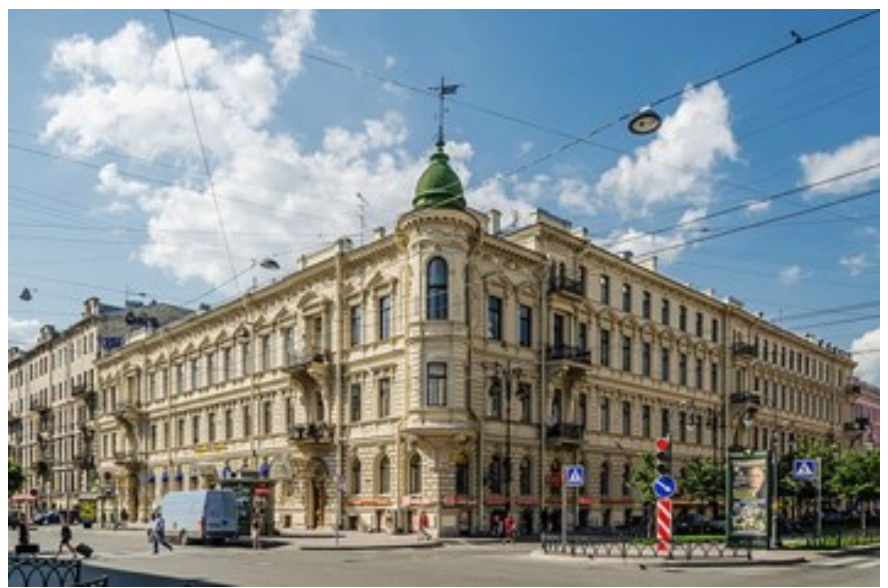

Сергиевская, 38. Архитектор Б.И.Гриикович (1892).

Мастерская А.Эберлинга-в надстройке на последнем этаже (на фото не видна).
Одна из достопримечательностей современного Петербурга - мастерская живописца Владимира Вячеславовича Загонека, заслуженного художника РФ, профессора, с 2006 г. руководителя персональной мастерской в Институте живописи, скульптуры и архитектуры. С 1904 г. просторное ателье с попарижски скошенным под потолком окном арендовал художник Альфред Рудольфович Эберлинг. Располагалось оно на последнем этаже доходного дома П.П. Вейнера, в престижной части Сергиевской улицы (в том же доме в 1907-1916 гг. размещалась редакция журнала «Старые годы»). Примечательно то, что мастерская оставалась за Эберлингом не только при царском режиме, но и при советском, счастливо пережив все бури эпохи. То же самое можно сказать и о ее хозяине. Он скончался в

1951 г., передав мастерскую своему любимому ученику - Вячеславу Загонеку, отцу теперешнего ее пользователя и хранителя. В наши дни здесь все остается в таком виде, будто первый хозяин ателье на минуту вышел за дверь.

Фамилия А. Эберлинга в наше время мало что говорит любителям искусства - в современные альбомы его произведения не включают, в постоянную экспозицию Третьяковской галереи или Русского музея они не входят. Его картины хранятся в фондах ГРМ, Театрального музея в Петербурге, Бахрушинского в Москве, в периферийных собраниях (например, в Барнауле), а также в частных собраниях за границей. А вот в начале века его фамилия была на слуху, обозреватели художественных выставок часто упоминали ее в рецензиях, особым успехом пользовались портреты. А сам художник прожил долгую и, по российским меркам, благополучную жизнь.

Эберлинг родился в 1872 г. в Лодзинском уезде - то есть на территории так называемой русской Польши. Подобно многим полякам, желавшим получить высшее художественное образование, он выехал с этой целью в Петербург. В 1898 г. он окончил Академию художеств (мастерская И. Репина) с присвоением звания художника I степени. В 1899 г. выехал с группой художников в Константинополь для выполнения правительственного задания по росписи православного храма. Именно там он приобрел распространенную в ту пору портативную фотокамеру Pocket Kodak и сделал первые снимки. С той поры начинается его увлечение художественной фотографией, так называемой светописью, что было в предреволюционные годы достаточно модным (в Петербурге известным художником светописи был, например, М. Шерлинг, которого портретировал Анненков). В этой области Эберлинг проявил себя как подлинный артист. Его уличные фотографии отличаются интересной композицией и эффектным освещением.

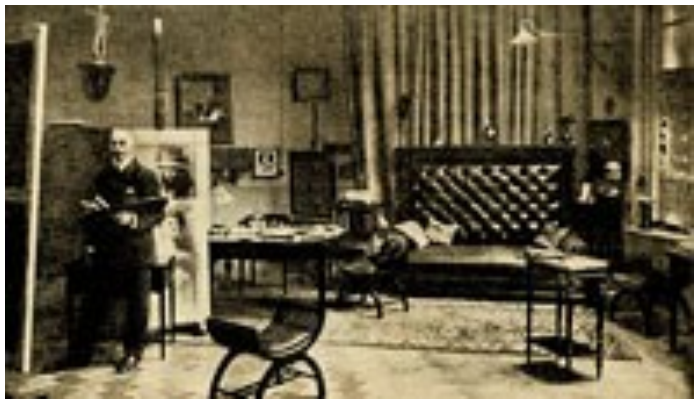

А.Эберлинг в своем ателье. В глубине - диван.

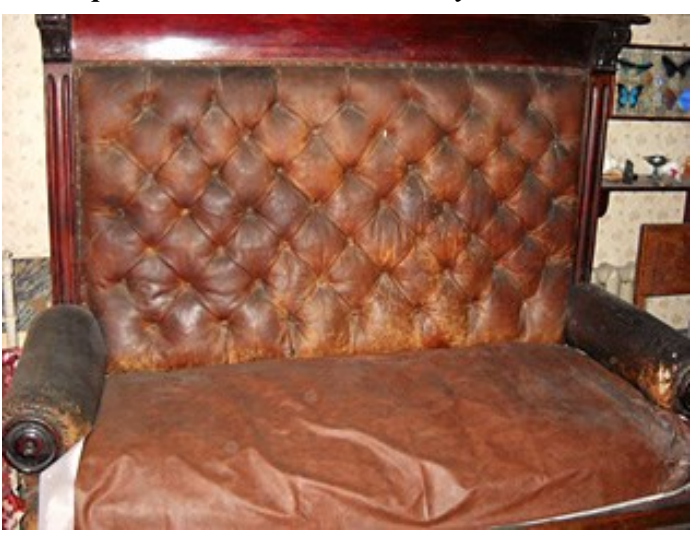

Тот жее диван в наше время. Мастерская В.Загонека. 


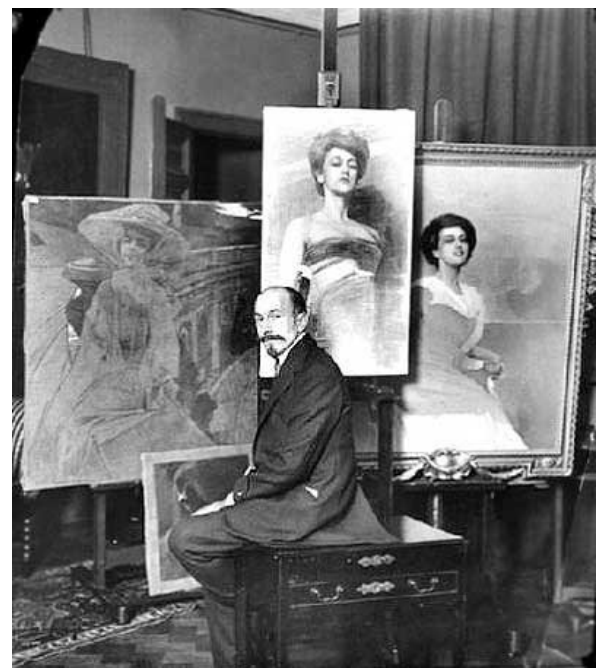

А.Эберлинг в мастерской.

На мольбертах - портреты балерин.

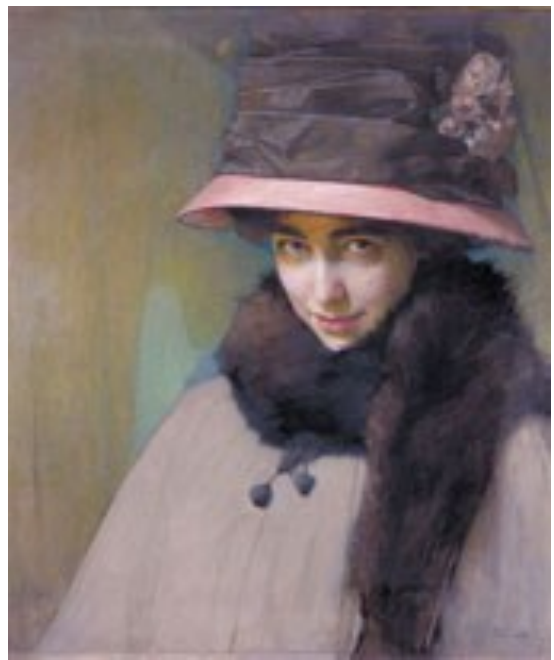

А.Эберлинг. Портрет Ирины Максимович (в аукционном каталоге был ошибочно назван портретом Тамары Карсавиной).

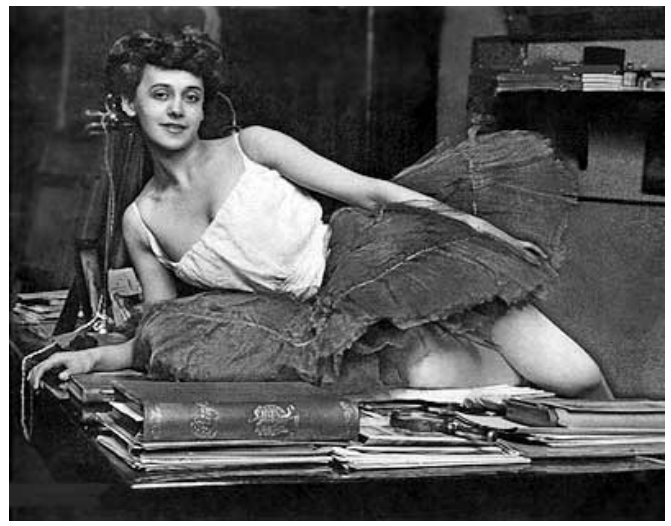

Тамара Карсавина на письменном столе в мастерской А.Эберлинга.

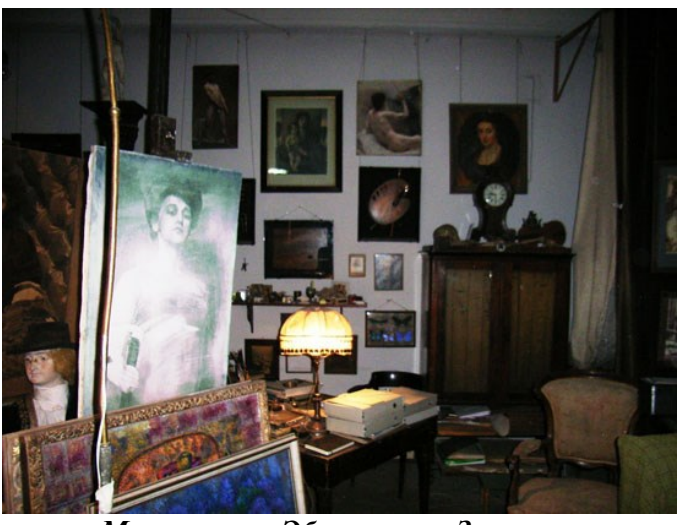

Мастерская Эберлинга-Загонека.

В центре - «стол Карсавиной»/
Дальнейшая карьера Эберлинга развивалась в русле стилистики умеренного модерна и реалистической живописи. Он выставлялся как в Петербурге, так и в Европе. В 1904 г. начал преподавать в Рисовальной школе Общества поощрения художеств. В 1905 г., после «кровавого воскресенья», Валентин Серов, до того регулярно исполнявший портреты по заказам царской семьи, не слишком вежливо отказался от этой миссии. Но порекомендовал для нее своего коллегу, А. Эберлинга, вполне благонадежного и уже зарекомендовавшего себя завзятым портретистом. На одном из листков перекидного календаря сохранилась памятная запись Эберлинга: «такого-то числа был представлен государю». Остальные следы своего придворного прошлого он, судя по всему, уничтожил в советское время. Заказы поступали постоянно, и Эберлинг стал автором многочисленных портретов членов венценосного семейства и придворных различного ранга, что вполне обеспечивало безбедное существование и возможность ежегодных поездок в Италию.

«Для себя» он в 1907 году задумал большое полотно «Храм Терпсихоры», на котором предполагал изобразить многих известных танцовщиц тех лет. Эта идея натолкнула мастера на мысль использовать для работы фотографии. Таким образом, балетные звезды тех лет - Анна Павлова, Тамара Карсавина, Матильда Кшесинская - позировали ему не только для живописных, но и - предварительно для фотографических портретов. Среди них немало актов. Великолепные снимки крупного формата до сих пор украшают ателье мастера. С Тамарой Карсавиной его связывали не только профессиональные отношения - насколько можно судить по количеству фотографий и по многолетней переписке. В любом случае, нетрудно заметить, что Карсавина была без сомнения любимой моделью художника. До сих пор в ненарушенном виде в мастерской стоит стол, на котором Тамара позировала для знаменитого «Фото на столе». Бережно сохраняется и старинный диван, резной бордюр которого виден на многих фотографиях. Более того, он до сих по-прежнему выполняет свои непосредственные функции.

После Февральской революции ни в каких реформах художественной жизни Эберлинг, насколько можно судить, участия не принимал. После Октябрьского переворота он вошел в число преподавателей Рисовальной школы, которым поручили реорганизовать свое заведение в Художественно-промышленный техникум. Эберлинг продолжал преподавать и в этом техникуме, и во Дворце пионеров, и в Доме художественного воспитания детей, а позже и в изостудии Дома ученых. В 1925-1930 гг. он руководил ленинградской студией АХРа, а в 1934 г. по приглашению одного из столпов советской художественной жизни И. Бродского занял место профессора живописи, рисунка и композиции в ЛИЖС (до 1937 г.).

Смена власти повлекла быструю и безболезненную смену тематики создававшихся мастером полотен. Левые течения в живописи не оказали на него ни малейшего воздействия ни до революции, ни после. Время расцвета модерна давно прошло, символистские сюжеты новой властью не приветствовались. Поэтому живопись Эберлинга советского периода в основном была традиционно-реалистической. Названия картин вполне отвечают духу времени: «Первые вести об Октябре в деревне» (1918) или «На рассвете» (первая премия на конкурсе «Великая русская революция» в 1923 г.). Состав моделей также изменился: «Портрет С. Орджоникидзе», «Портрет стахановки Смирновой», «Портрет М. Горького» (все 1937), «Портрет балерины Семёновой» (1940, дань прежнему увлечению), «В. И. Ленин в 1895 году», «Портрет Ушинского», «Портрет В. И. Ленина» (все 1946), «Портрет И. Сталина», «Портрет академика Н. Г. Хлопина» (оба 1947), «Портрет академика С. П. Давиденкова» (1951) и другие. 


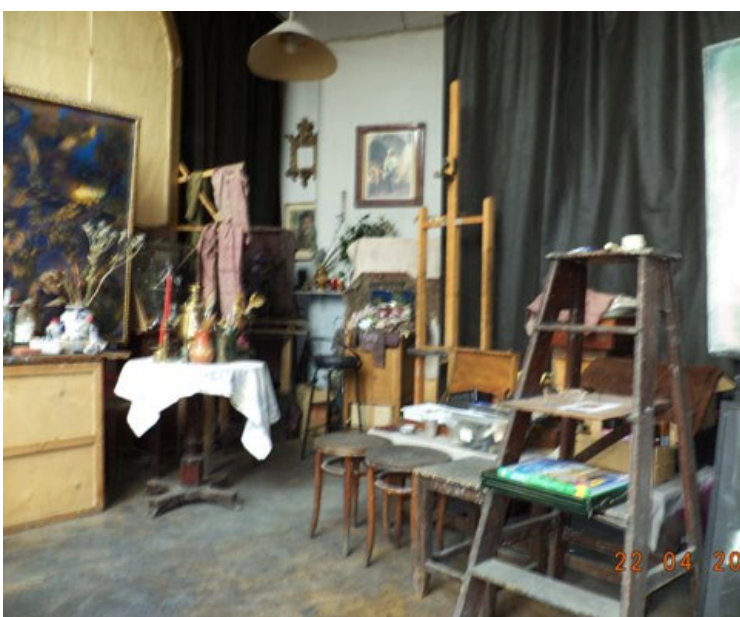

Бывщее ателье А.Эберлинга, ныне - мастерская Владимира Загонека.
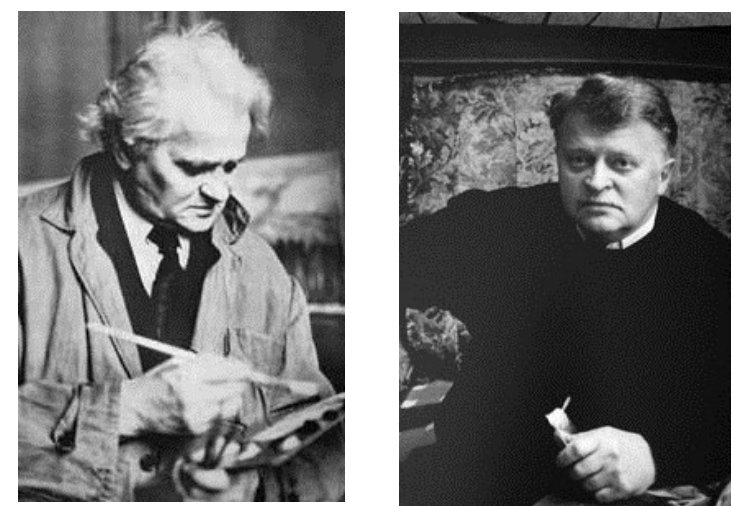

На фото слева - Вячеслав Загонек (1919-1994), художник-живописец. На фото справа-его сын, такж⿻е художсник-Владимир Загонек, нынешний хранитель мастерской А.Эберлинга.

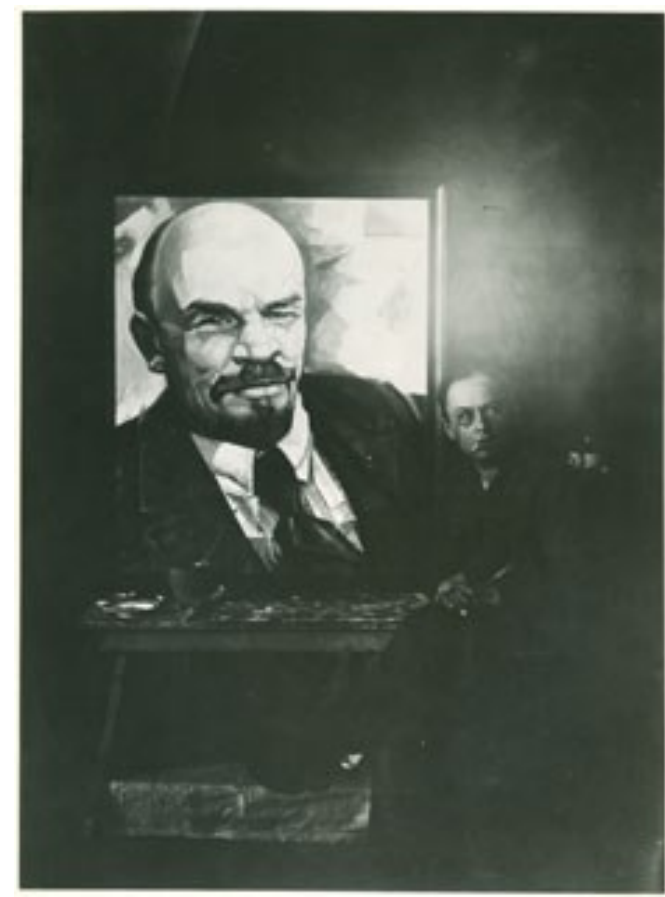

Юрий Анненков в своей мастерской. На мольберте-портрет Ленина. Москва. 1924.

Заложенное в характере отсутствие социальной пассионарности позволило художнику избежать конфликтов с властью и остаться в профессии, наполнив прежние профильные темы новым содержанием. Он был осторожен и никогда не стремился занимать высокие должности, предпочитая оставаться в тени. Его мастерство всегда привлекало к нему множество учеников. Конечно, как и все остальные, он боялся репрессий, особенно учитывая свое прошлое положение при дворе. Они его миновали, хотя не обошлось без серьезных стрессов и потерь в годы различных катаклизмов. В начале войны Эберлингу и его жене обещал помочь с выездом из Ленинграда какойто энкаведешник, но обманул и обокрал их, супруги с трудом выбрались из осажденного города и, в общем-то, чудом остались в живых. Но при всех потерях многое удалось сохранить, прежде всего - мастерскую музейного уровня.

С Анненковым Эберлинга связывают лишь косвенные обстоятельства. В 1924 г. оба они приняли участие в закрытом правительственном конкурсе на официальный портрет В.И. Ле-нина. В ДМВ Анненков сообщает об этом конкурсе и о том, что его портрет занял первое место. Книга теперь довольно широко известна, так что эти сведения без какой-либо проверки неоднократно повторялись как в биографиях Анненкова, так и в других текстах. Читателей книги, коллекционеров и историков искусства волновал не столько вопрос первого места, сколько то, куда в конце концов делся пресловутый портрет. Вопреки сообщению Анненкова, что он был воспроизведен на почтовых марках, ни один филателистический каталог этого не подтверждает. Возможно, Гознак сообщил художнику о намерении отпечатать марки, а ему не пришло в голову проверять, было ли реализовано это намерение. Но даже если портрету не нашли применения, то уничтожать его как будто повода не было. Как бы то ни было, присуждение первого места именно Анненкову сомнению не подвергалось. И вдруг выяснилось, что Эберлинг также был в числе приглашенных на конкурс и, как он утверждает в письме заместителю председателя АХРа, написанному в конце 1920-х - начале 1930-х гг., также получил первую премию!

С целью выяснить это противоречие редакция ВА побывала в мастерской Владимира Загонека, который в данном случае выступил не только как гостеприимный хозяин, но и как эксперт по щекотливому вопросу.

Начать следует с того, что документированной историей конкурса до сих пор никто не интересовался. Нам неизвестны достоверно ни его участники, ни победители. Публикации на эту тему пока не обнаружены, в биографиях предполагаемых участников этот эпизод, как будто, не был отражен. Это легко понять, поскольку конкурс был закрытым, а участников выбирал Гознак, считавший все это своим внутренним делом. Во всяком случае, пока что мы располагаем лишь сведениями, исходящими от Анненкова и Эберлинга.

В архиве Анненкова сохранилось письмо Гознака от 22 марта 1924 г. (которое он полностью приводит в ДМВ) с предложением принять участие в конкурсе и с изложением требований к технике и стилистике будущего портрета вождя, а также с указанием срока его выполнения и финансовых условий. Последний пункт оказался по тем временам весьма привлекательным, и Анненков тут же взялся за работу - сроки поджимали. Далее он пишет, что готовый портрет был сдан за 3-4 дня до «крайнего срока» (15 мая 1924 г.) , а примерно через месяц он получил извещение о присуждении первой премии. Выплаченная ему сумма в 1000 руб. пришлась весьма кстати, потому что уже в конце июля Анненков вместе со второй женой отбыл в Италию. 

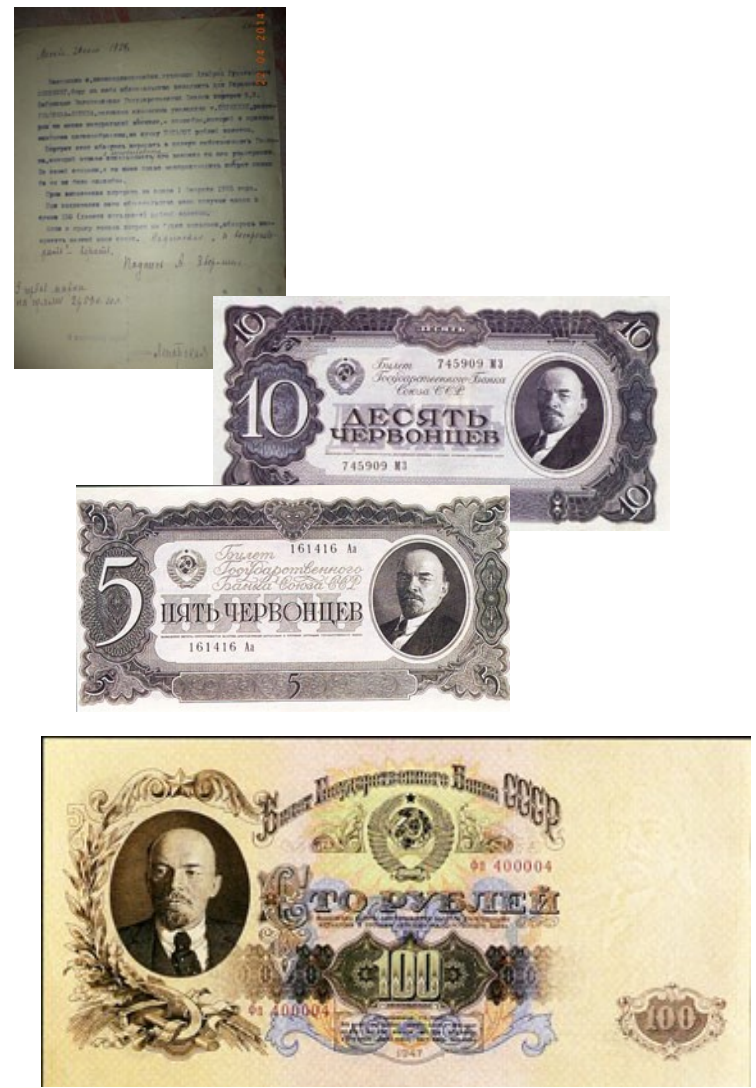

Фото наверху: обязательство о выполнении портрета Ленина, подписанное А.Эберлингом. Нижсе: Купюры с портретом Ленина работы Эберлинга: 10 и 5 червонцев образца 1937 г. и 100 рублей образца 1947 2. (в правой части купюры чуть просматривается портрет Ленина на водяном знаке).

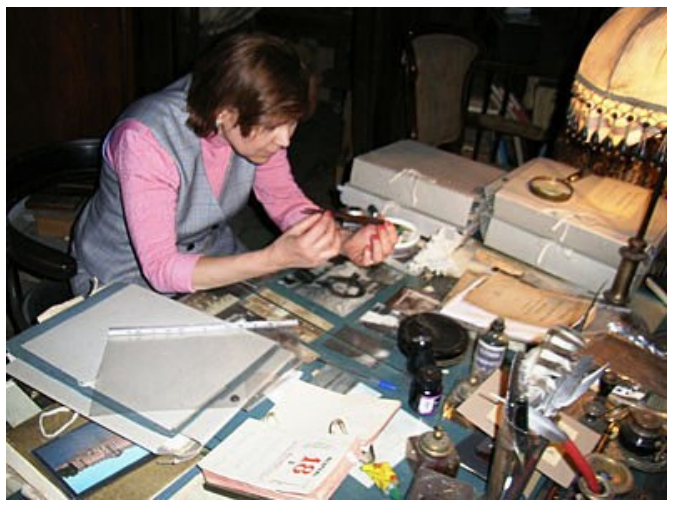

Светлана Левочко за историческим столом.

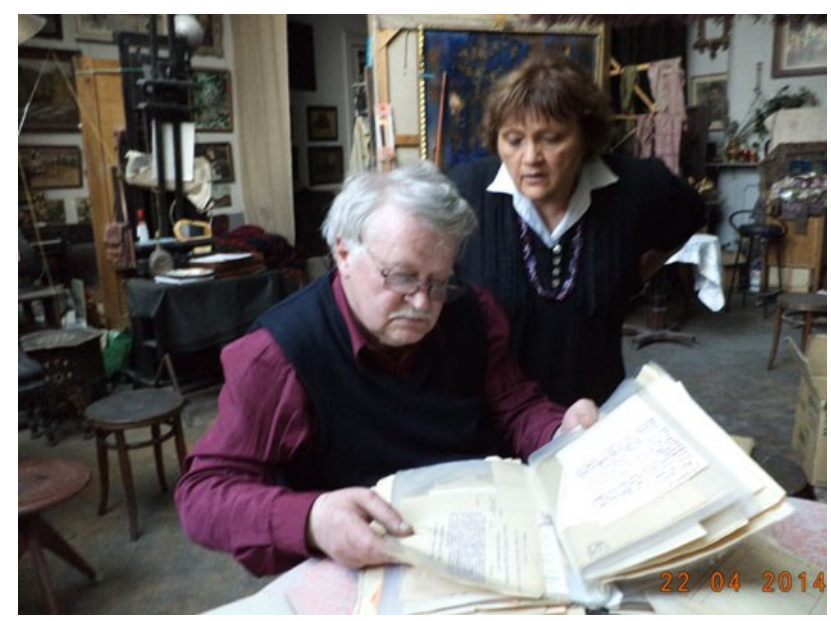

Владимир Загонек и Ирина Обухова-Зелиньская рассматривают документы из архива А.Эберлинга
В архиве Эберлинга сохранился документ (с его собственноручной подписью и с тремя гербовыми марками на сумму 2 р. 50 к. зол[отом]), в котором он обязуется выполнить для Гознака портрет В.И.Ленина к указанному сроку - 1 февраля 1925 г. Это обязательство (фактически - договор) датировано 26 октября 1924 г. О конкурсной основе заказа в тексте ничего не говорится.

Какие выводы можно сделать при сравнении этих документов? Прежде всего обращает на себя внимание разница в сроках. Эберлинг подписывает обязательство-договор спустя 4 месяца после того, как Анненкову была выплачена премия. Участвовал ли он в объявленном в марте конкурсе? Или получил заказ на портрет уже после него и после отъезда Анненкова? Пока что на эти вопросы нет ответа. В информационном письме Гознака оговаривается, что будут приобретены все представленные портреты, а не только премированные. То есть это был скорее коллективный заказ, где выбор оставался за заказчиком, а в случае необходимости комиссия Гознака могла пролонгировать конкурс или объявить второй тур.

Что касается приоритета Эберлинга, то он базируется на том несомненном факте, что именно его портрет Ильича был использован Гознаком - купюры достоинством в 1, 3, 5 и 10 червонцев с вышеуказанным портретом выпускались начиная с 1937 г. На госбанковских билетах в 50 и 100 руб. образца 1947 г. портреты были уже другие (с фотографии П.Оцупа), но эберлинговский портрет вождя фигурировал на них в виде водяного знака. (Сведения приведены по: Сенкевич Д.А. Государственные денежные знаки РСФСР и СССР: Каталог. - М., Межнумизматика, 1988. С. 184, 190). Все это верно, но тут опять возникает вопрос в связи с датами. Портрет воспроизвели на денежных купюрах лишь в 1937 году через 13 лет после подписания договора!

В.Загонек выдвигает следующее объяснение. Анненковский портрет, судя по всему, действительно занял первое место, раз ему прислали об этом уведомительное письмо и выплатили премию (в архиве Эберлинга такого письма нет, а сам он вспоминал, что получил в виде оплаты 500 руб.). Но ведь Анненков тут же уехал за границу, а Эберлинг не только остался в стране, но и начинал новый жизненный этап как активный член AXP и автор идеологически выдержанных полотен, не говоря уже о более поздних портретах членов ВЦИК. К тому же его портрет бесспорно отвечал стилистическим и художественным требованиям Гознака (в отличие от явно «подкубленного» портрета Анненкова). Поэтому позже пальму первенства получил Эберлинг.

Эта версия требует некоторых уточнений. В первые 4 года проживания в Париже Анненкова продолжали считать советским художником. Он выполнил заказ полпредства на репрезентативный портрет Л.Красина, написал две статьи для «Парижского вестника». То есть пока он не стал «невозвращенцем» в 1929-30 гг. ничто, казалось бы, не мешало Гознаку использовать утвержденный портрет Ленина по назначению. Этого, как видим, не произошло. Но и портрет Эберлинга почему-то был использован только через 13 лет. Пока что у нас нет ответов на неизбежно возникающие вопросы. Видимо, пока не будут обнаружены новые документы в глубинах Гознака или свидетельства других свидетелей событий, вряд ли мы сможем выйти за рамки предположений. 
В заключение Владимир Загонек поделился воспоминаниями о том, как его отец, художник Вячеслав Загонек, выбрал в свое время себе в учителя именно Эберлинга, как сохранял всю обстановку мастерской и как уже в послевоенное время в этой же мастерской у отца собирались художники и писатели. О том, как он сам продолжает традиции отца и какие заботы легли на его плечи в связи с содержанием мастерской. Что-то было отремонтировано и подправлено собственными силами, но вот пришедшее за сто лет в негодность огромное окно требует дорогостоящего ремонта...

\section{Владими р 3 агонек}

\section{отвеч а т на нашу анкету}

Когда Вы прочли в первый раз ДМВ? Каким образом к Вам попала эта книга?

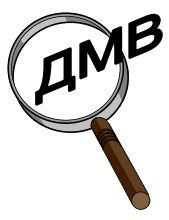

Я прочел ее не так давно, лет 10-15 назад. Но не раньше 1999 г. Хорошо это помню, потому что теща подарила на день рождения. Это не первая книга, которая таким образом у меня оказывается.

Ваши впечатления? Что запомнилось, удивило, вызвало сомнения и т.д.?

Прочел с интересом. Но у меня появилось ощущение, что Анненков какой-то обиженный, закомплексованный. Может быть, тем, что он уехал, а его друзья остались и сделали карьеру. Он же был первоклассный художник. Мог бы здесь быть на месте А. Герасимова (советский живописец, первый президент АХ СССР, лауреат 4-х сталинских премий (1941, 1943, 1946, 1949), член ВКП(б) с 1950 г. - прим. Ред.)

- Вы думаете, он смог бы занять положение Герасимова?

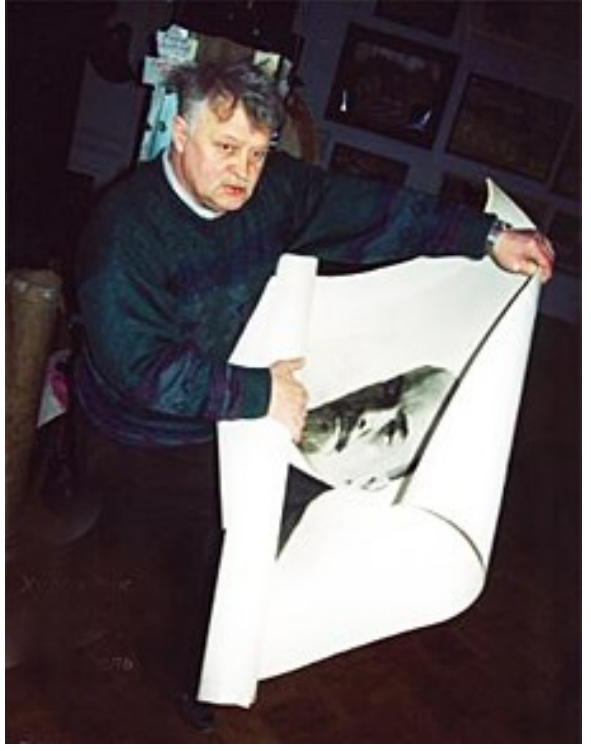

Владимир Загонек с портретом Ленина работы А.Эберлинга.

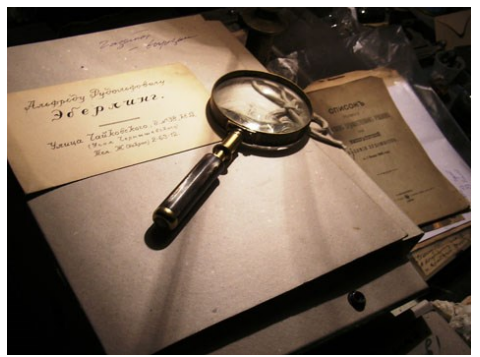

- А почему нет? Он же был очень амбициозный, даже в книге все время пишет «я сделал... я первый нарисовал... я занял первое место...» - Может быть, он хотел рассказать читателям что-то о себе? Ведь в СССР о нем не упоминали почти 30 лет.

- Да его и так все знали.

- И молодежь?

- Конечно. Я работы Анненкова, разумеется, знал и в молодости. Например, в студенческие времена (1960-е) видел в ГРМ, еще при Пушкареве, и «Красную конницу» Малевича, и портрет Шерлинга Анненкова.

- Может быть, на выставке? В постоянной экспозиции его не было до 1988 г. (по данным ГРМ).

- Этого не помню. Возможно. Вообще, часто говорят, что в СССР запрещалось то да се. Вот, например, импрессионисты. Якобы были запрещены. А в 1944 г. в Союзе художников прошел вечер памяти Ренуаpa.

- Однако же, Вы сами видите, персональная выставка Анненкова состоялась впервые только сейчас.

- Ну, это наверно потому, что большинство его работ во Франции.

Перечитывали ли Вы ДМВ позже (например, в последнее время)? Изменилось ли Ваше отношение к тексту?

- Нет, позже не перечитывал. Но теперь думаю, что надо бы перечесть, проверить свои впечатления - может быть, теперь я буду иначе воспринимать его.

Ваше мнение по поводу места и роли творчества Ю. Анненкова в русском искусстве XX в.?

- Ну, какую я могу дать оценку? Оценка - самая высокая. Художник первоклассный.

Какие произведения и книги Ю. Анненкова есть в Вашем собрании? Каким образом они к Вам попали? - Больше ничего нет, только вот это издание ДМВ.

Визит в мастерскую В. Загонека состоялся 22 апреля 2014 г. С художником беседовали И.Обухова-Зелиньская и С.Левошко. Для биографического очерка А.Эберлинга были использованы устные сообщения В.Загонека, статья В.Никитина «Фотограф Серебряного века. Светопись художника Эберлинга» (http://www.fotonovosti.ru/content/ news one/9/9848 ), информация Википедии. Редакция приносит благодарность В. Загонеку за предоставление для публикации фотографий и документов из своего архива.

Учредитель - Общество друзей Ю. Анненкова

Редколлегия - Бригада Отчаянных Добровольцев

Главный редактор - И. Обухова-Зелиньская obuchowa.irina@gmail.com

Отв. редактор выпуска - М. Гоголин Gogless@yandex.ru

При перепечатке материалов ссылка на «ВА» обязательна

Подписано в печать 15.05.2014. 